\title{
1,3- $\beta$-Glucan synthase in cell-free extracts from mycelium and protoplasts of Sclerotium glucanicum
}

\author{
Elke Kottutz and Peter Rapp*† \\ Institut für Biochemie und Biotechnologie der Technischen Universität Braunschweig, FRG
}

(Received 8 December 1989; revised 27 March 1990; accepted 6 April 1990)

\begin{abstract}
Conditions for obtaining stable protoplasts from Sclerotium glucanicum and their reversion to hyphal growth were determined. 1,3- $\beta$-Glucan synthase activity was detected in particulate enzyme fractions from mycelium and protoplasts of Scl. glucanicum. UDP-|U-14 Clglucose was linearly incorporated into a $\beta$-glucan for about 20 min at $25^{\circ} \mathrm{C}$. Optimum pH and temperature values, as well as thermal stabilities of the 1,3- $\beta$-glucan synthase activity, were determined. High concentrations of EDTA were inhibitory. Enzyme activity was stimulated by ATP and GTP. The apparent $K_{\mathrm{m}}$ value for UDP-glucose was 0.54 mM. The reaction product was characterized as 1,3- $\beta$ glucan by ${ }^{13} \mathrm{C}$ NMR spectroscopy and hydrolysis products of an exo-1,3- $\beta$-glucanase.
\end{abstract}

\section{Introduction}

1,3- $\beta$-Glucan synthase (UDP-glucose : 1,3- $\beta$-glucan 3 $\beta$-D-glucosyltransferase; EC 2.4.1.34) has been isolated from a wide range of yeasts and other fungi (Shematek $e t$ al., 1980; Cerenius \& Söderhäll, 1984; Girard \& Fèvre, 1984; Quigley \& Selitrennikoff, 1984; Szaniszlo et al., 1985; Andaluz et al., 1986; Finkelman \& Vardanis, 1987; Kominato et al., 1987; Beauvais \& Latgé, 1989). Shematek et al. (1980) demonstrated that the 1,3- $\beta$ glucan synthase from Saccharomyces cerevisiae, like the chitin synthase, is located in the plasma membrane, facing the cytoplasm. Both of these enzymes play a major role in cell wall biosynthesis of higher fungi (Gooday \& Trinci, 1980; Catley, 1983). Pulse-chase experiments with $\left[{ }^{14} \mathrm{C}\right]$ glucose suggested that in growing hyphae of Schizophyllum commune water-soluble $\beta$-glucan is a precursor for the alkali-insoluble chitin- $\beta$-glucan complex in the wall (Wessels et al., 1983). Studies with yeasts and other fungi have shown that 1,3- $\beta$-glucan synthase activity is stimulated by nucleoside triphosphates, especially ATP, GTP and their analogues (Shematek et al., 1980; Shematek \& Cabib, 1980; Orlean, 1982; Cerenius \& Söderhäll, 1984; Szaniszlo et al., 1985; Kang \& Cabib, 1986; Kominato et al., 1987).

In the present work the biosynthesis of $1,3-\beta$-glucan of

$\dagger$ Present address: Gesellschaft für Biotechnologische Forschung mbH, D-3300 Braunschweig, FRG

\footnotetext{
Abbreviations: DMSO, dimethyl sulphoxide; DMSO-d 6 , hexa-
} deuterodimethyl sulphoxide.
Sclerotium glucanicum was studied since this fungus is known for its ability to excrete large amounts of watersoluble 1,3- $\beta-/ 1,6-\beta$-glucan (Halleck, 1967; Rodgers, 1973; Rapp, 1989). This polysaccharide, which has been termed scleroglucan, is built up from $1,3-\beta$-linked glucans with branches of single glucose groups $1,6-\beta$ linked to every third residue of the main chain (Johnson et al., 1963; Rinaudo \& Vincendon, 1982). Like many other fungi Scl. glucanicum most probably also contains $1,3-\beta$-glucans linked with 1,6- $\beta$-glucosyl or oligosaccharide residues as wall components. The following experimental results describe the conditions for the formation and regeneration of protoplasts and the preparation and properties of 1,3- $\beta$-glucan synthase from $S c l$. glucanicum.

\section{Methods}

Chemicals. UDP-[U-14 C]glucose $\left(323 \mathrm{mCi} \mathrm{mmol}^{-1} ; 11.9 \mathrm{GBq}\right.$ $\mathrm{mmol}^{-1}$ ) was purchased from Amersham. $\beta$-Glucuronidase containing enzyme preparation type HP-2 from Helix pomatia, laminarinase from Penicillium sp., laminarin and lichenan were obtained from Sigma. Novozym 234 from Trichoderma harzianum was a product from Novo Industri. Periodate-oxidized laminarin was prepared according to Goldstein et al. (1965). Pustulan was obtained from Calbiochem, amylose from Merck and sodium carboxymethylcellulose from Serva. Emulsifier Scintillator $299^{\mathrm{TM}}$ was purchased from Packard. Extracellular 1,3- $\beta$ - /1,6- $\beta$-glucan (scleroglucan) was isolated and purified according to Rapp et al. (1979). All other reagents were analytical grade from commercial sources.

Growth of mycelium and preparation of protoplasts. Sclerotium glucanicum (NRRL 3006, obtained from CBS, Baarn, The Netherlands) was cultivated according to Rapp (1989). Mycelium grown for $36 \mathrm{~h}$ in 
basal medium with $20 \mathrm{~g}$ glucose $1^{-1}$ was aseptically harvested by centrifugation at $6000 \mathrm{~g}$ at $4{ }^{\circ} \mathrm{C}$ and washed several times with sterile $0.88 \%(\mathrm{w} / \mathrm{v}) \mathrm{NaCl}$ solution. Protoplasts were prepared by aseptically incubating mycelium ( $100 \mathrm{mg}$ wet weight $\mathrm{ml}^{-1}$ ) in 2 to $3 \mathrm{ml}$ medium containing $1 \cdot 1 \mathrm{M}$-sucrose, $\mathrm{pH} 5 \cdot 5$, and wall lytic enzyme preparations ( 3 to $7 \mathrm{mg}$ protein $\mathrm{ml}^{-1}$ ) in closed flasks at $37^{\circ} \mathrm{C}$ for $12 \mathrm{~h}$ with gentle shaking. When $1 \cdot 1 \mathrm{M}$-sorbitol, $0.9 \mathrm{M}-\mathrm{KCl}, 0.9 \mathrm{M}-\mathrm{NaCl}$ or $0.6 \mathrm{M}-\mathrm{MgSO}_{4}$ solutions were used as osmotic stabilizers they were adjusted to $\mathrm{pH} \mathrm{5.5.}$ Samples were counted for protoplasts in a haemocytometer. Nondigested mycelium and cell debris were aseptically removed by low speed centrifugation. Floating protoplasts were separated from those with higher density by centrifugation at $1200 \mathrm{~g}$ at room temperature for 5 to $10 \mathrm{~min}$ and removed with a Pasteur pipette. The sedimented protoplasts were washed three times with sterile $1 \cdot 1 \mathrm{M}$-sucrose, $\mathrm{pH} 5 \cdot 5$, and gently resuspended in sterile sucrose solution.

Regeneration of protoplasts. About 100 protoplasts in $0.5 \mathrm{ml} 1.1 \mathrm{M}$ sucrose solution, $\mathrm{pH} 5 \cdot 5$, were aseptically plated on $20 \mathrm{ml}$ regenerating agar containing, per litre: $100 \mathrm{~g}$ sucrose, $10 \mathrm{~g}$ yeast extract and $30 \mathrm{~g}$ agar. The regenerating agar was overlaid with $1 \mathrm{ml} 1 \cdot 1 \mathrm{M}$-sucrose solution, pH 5.5, and incubated at $30^{\circ} \mathrm{C}$. Reversion to the mycelial form was observed by phase-contrast microscopy.

Preparation of particulate 1,3- $\beta$-glucan synthase from protoplasts. Protoplasts suspended in $0.05 \mathrm{M}$-Tris/ $\mathrm{HCl}$ buffer, $\mathrm{pH} 7.5$, containing $5 \mathrm{~mm}-\mathrm{MgSO}_{4}, 7 \mathrm{~mm}$-cellobiose and $1 \mathrm{~mm}$-EDTA were ultrasonically disrupted at $4{ }^{\circ} \mathrm{C}$ for $10 \mathrm{~s}$ (Sonifier J-17-A, Branson). A microtip was used and the output control was set at 7 . Membranes were collected by centrifugation at $34000 \mathrm{~g}$ for $1 \mathrm{~h}$ at $4{ }^{\circ} \mathrm{C}$.

Preparation of particulate 1,3- $\beta$-glucan synthase from mycelium. Wet mycelium $(100 \mathrm{~g})$, grown for $48 \mathrm{~h}$ was washed thoroughly with $0.88 \%$ $(\mathrm{w} / \mathrm{v}) \mathrm{NaCl}$ solution to liberate the cells from adhering extracellular, water-soluble $1,3-\beta-/ 1,6-\beta$-glucan. Cells were suspended in $250 \mathrm{ml}$ icecold $0.05 \mathrm{M}-\mathrm{Tris} / \mathrm{HCl}$ buffer, $\mathrm{pH} 7.5$, containing $7 \mathrm{mM}-\mathrm{MgSO}_{4}$ and 1 mM-EDTA. Mycelium was disrupted in a Waring blender (maximum output) for $10 \mathrm{~min}$ at $6^{\circ} \mathrm{C}$. Samples were examined microscopically to confirm that most hyphae had been disrupted. The resulting extract was diluted with $125 \mathrm{ml}$ ice-cold $0.05 \mathrm{M}$-Tris/HCl buffer, $\mathrm{pH} 7.5$, containing $7 \mathrm{mM}-\mathrm{MgSO}_{4}$ and $1 \mathrm{mM}$-EDTA. Residual hyphae and cell walls were separated by centrifugation at $3000 \mathrm{~g}$ at $4{ }^{\circ} \mathrm{C}$ for $20 \mathrm{~min}$. The supernatant was centrifuged at $34000 \mathrm{~g}$ at $4{ }^{\circ} \mathrm{C}$ for $1 \mathrm{~h}$. The membrane fraction obtained was used as the enzyme source. Prior to use in the 1,3$\beta$-glucan synthase assay $0.2 \mathrm{~g}$ of the membrane fraction was ultrasoni-

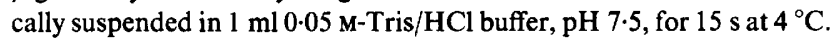

1,3- $\beta$-Glucan synthase assay. The standard incubation mixture contained $50 \mathrm{~mm}$-Tris/HCl buffer, $\mathrm{pH} 7.5,0.08 \mathrm{mM}-\mathrm{UDP}-\left[\mathrm{U}-{ }^{14} \mathrm{C}\right] \mathrm{glu}-$ cose $\left(0.25 \mathrm{mCi} \mathrm{mol}^{-1} ; 9.3 \mathrm{MBq} \mathrm{mol}^{-1}\right), 0.4 \mathrm{mM}^{-U D P}$-glucose, $1 \mathrm{mM}$ $\mathrm{MgCl}_{2}$ and 18.5 to $42.5 \mu \mathrm{g}$ enzyme protein in a final volume of $400 \mu \mathrm{l}$. After incubation at $25^{\circ} \mathrm{C}$ for $20 \mathrm{~min}$ the reaction was stopped by heating in boiling water for $3 \mathrm{~min}$. The reaction mixture was cooled to room temperature, $1.5 \mathrm{ml} 95 \%(\mathrm{v} / \mathrm{v})$ ethanol was added, and the mixture was allowed to stand overnight at $4{ }^{\circ} \mathrm{C}$. In order to remove unreacted UDP-glucose the pellet obtained after centrifugation at $7450 \mathrm{~g}$ at room temperature was washed three times with $1.5 \mathrm{ml} 70 \%$ (v/v) ethanol, suspended in $0.5 \mathrm{ml} 98 \%(\mathrm{v} / \mathrm{v})$ ethanol and transferred to scintillation vials. Scintillator $(3 \mathrm{ml})$ was added and the sample counted in a liquid scintillation spectrometer (Packard).

Determination of solubility of the 1,3- $\beta$-glucan synthase product. About $5 \mathrm{mg}$ radioactive product was mixed with $0.5 \mathrm{ml}$ solvent and gently shaken for $24 \mathrm{~h}$ at room temperature under nitrogen atmosphere. Insoluble material was recovered by centrifugation at $7450 \mathrm{~g}$ at $20^{\circ} \mathrm{C}$ and washed three times with $1.5 \mathrm{ml} 70 \%(\mathrm{v} / \mathrm{v})$ ethanol. The pellet obtained was suspended in $0.5 \mathrm{ml} 98 \%(\mathrm{v} / \mathrm{v})$ ethanol, $3 \mathrm{ml}$ scintillator was added and the sample was counted in a scintillation spectrometer.
Enzymic digestion of the $\beta$-glucan synthase product by laminarinase from Penicillium $s p$. Of the $\beta$-glucan synthase product, prepared and purified as described above, 0.3 to $0.4 \mathrm{mg}$ was dissolved in $0.5 \mathrm{ml}$ dimethyl sulphoxide (DMSO) at $21^{\circ} \mathrm{C}$ for $24 \mathrm{~h}$. After centrifugation at $7450 \mathrm{~g}$ the supernatant was evaporated to dryness at $20^{\circ} \mathrm{C}$ under reduced pressure. The resultant $\beta$-glucan was suspended in $0.5 \mathrm{ml}$ $0.05 \mathrm{M}$-sodium acetate buffer, $\mathrm{pH} 5.0$, containing $0.3 \mathrm{mg}$ laminarinase and incubated at $37^{\circ} \mathrm{C}$ for $2 \mathrm{~h}$. Hydrolysis of the $\beta$-glucan was stopped by heating the mixture in boiling water for $5 \mathrm{~min}$.After centrifugation at $7450 \mathrm{~g}$ the supernatant was subjected to thin-layer chromatography (TLC) and high-performance liquid chromatography (HPLC).

Determination of substrate specificity and hydrolysis products of laminarinase from Penicillium sp. Substrate $(100 \mathrm{mg})$ (laminarin, periodate-oxidized laminarin, pustulan, lichenan, extracellular $1,3-\beta-$ /1,6- $\beta$-glucan, amylose, sodium carboxymethylcellulose) and $1 \mathrm{mg}$ laminarinase in $20 \mathrm{ml} 0.07 \mathrm{M}$-sodium phosphate buffer, $\mathrm{pH} 5.0$, were incubated at $37^{\circ} \mathrm{C}$ for $1 \mathrm{~h}$. The reaction was stopped by heating in boiling water for $5 \mathrm{~min}$. After centrifugation at $7450 \mathrm{~g}$ the products were assayed by the method of Somogyi (1952) and by TLC. Glucose was measured with a Glucose Analyzer (Yellow Spring Instruments) (Rapp, 1989).

$T L C$. This was done on silica gel $60 \mathrm{~F}_{245}$ plates $(0.25 \mathrm{~mm}$, Merck) and chromatographed twice in $n$-butanol/ethanol/water $(3: 5: 2$, by vol.) or in ethyl acetate/propan-2-ol/water (20:13:7, by vol.). Sugars were detected by spraying with anisaldehyde/sulphuric acid reagent (Krebs et al., 1967). Labelled sugars were located by scanning for radioactivity with a Berthold Scanner.

HPLC. Sugars were separated by HPLC at room temperature using a 112 Solvent Delivery Module (Beckman) coupled to a Lichrosorb RP18 column $(4 \mathrm{~mm} \times 25 \mathrm{~cm}$, Merck). Refractive index was monitored by a 156 refractive index detector (Beckman). Distilled water was used as

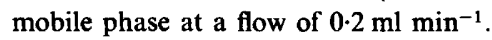

${ }^{13} \mathrm{C}$ NMR spectroscopy. Proton decoupled ${ }^{13} \mathrm{C}$ NMR spectra were obtained in the Fourier transform mode with a Bruker AM-300 spectrometer at $75 \mathrm{MHz}$ and $80^{\circ} \mathrm{C}$. Hexadeuterodimethyl sulphoxide (DMSO- $\mathrm{d}_{6}$ ) was used as the solvent.

\section{Results}

\section{Protoplast formation}

Among the enzymes used to release protoplasts from hyphae of Scl. glucanicum the commercial enzyme preparation Novozym 234 was found to be the most suitable (Table 1 ). High yields of 2 to $3 \times 10^{7}$ protoplasts $\mathrm{ml}^{-1}$ were obtained when $100 \mathrm{mg}$ wet mycelium ml-1 was incubated with $7 \mathrm{mg}$ Novozym $234 \mathrm{ml}^{-1}$ in $1.1 \mathrm{M}-$ sucrose or sorbitol at pH 5.5 and $37^{\circ} \mathrm{C}$ for $12 \mathrm{~h}$. Fewer protoplasts $-7.5 \times 10^{6}, 4.4 \times 10^{6}$ and $7.6 \times 10^{5}(100 \mathrm{mg}$ wet mycelium $)^{-1}$ - were produced using $0.9 \mathrm{M}-\mathrm{KCl}$, $0.6 \mathrm{M}-\mathrm{MgSO}_{4}$ and $0.9 \mathrm{M}-\mathrm{NaCl}$ as osmotic stabilizers. When the $\beta$-glucuronidase-containing preparation from $H$. pomatia was used as lytic enzyme preparation $0.6 \mathrm{M}-$ $\mathrm{MgSO}_{4}$ was found to be the best among the five stabilizers studied. Approximately $2.9 \times 10^{6}$ protoplasts $(100 \mathrm{mg} \text { wet mycelium })^{-1}$ were obtained with $0.6 \mathrm{M}$ - 
Table 1. Release of protoplasts by different lytic enzyme preparations

\begin{tabular}{|c|c|c|c|}
\hline Enzyme preparation & $\begin{array}{l}\text { Enzyme concentration } \\
\left(\mathrm{mg} \mathrm{ml}^{-1}\right)\end{array}$ & $\begin{array}{l}\text { Enzyme activity } \\
\quad\left(\mathrm{U} \mathrm{ml}^{-1}\right)\end{array}$ & $\begin{array}{l}\text { Yield of protoplasts } \\
(100 \mathrm{mg} \text { wet mycelium })^{-1}\end{array}$ \\
\hline $\begin{array}{l}\beta \text {-Glucuronidase-containing enzyme } \\
\text { preparation from } H \text {. pomatia }\end{array}$ & $30 \mu \mathrm{ml}^{-1}$ & $405^{*}$ & $6.25 \times 10^{5}$ \\
\hline Laminarinase from Penicillium sp. & $3 \cdot 0$ & $15 \dagger$ & $1.48 \times 10^{4}$ \\
\hline $\begin{array}{l}\beta \text {-Glucuronidase-containing enzyme } \\
\text { preparation from } H \text {. pomatia }\end{array}$ & $30 \mu 1 \mathrm{ml}^{-1}$ & $405^{*}$ & $2.76 \times 10^{6}$ \\
\hline and laminarinase from Penicillium sp. & $3 \cdot 0$ & $15 \dagger$ & \\
\hline Novozym 234 from $T$. harzianum & $7 \cdot 0$ & ND & $2.67 \times 10^{7}$ \\
\hline$\beta$-Glucanases from Scl. glucanicum & $3 \cdot 8$ & $15 \dagger$ & $8.52 \times 10^{3}$ \\
\hline
\end{tabular}

ND, Not determined. $\quad * \beta$-Glucuronidase activity. $†$ Activity towards laminarin.

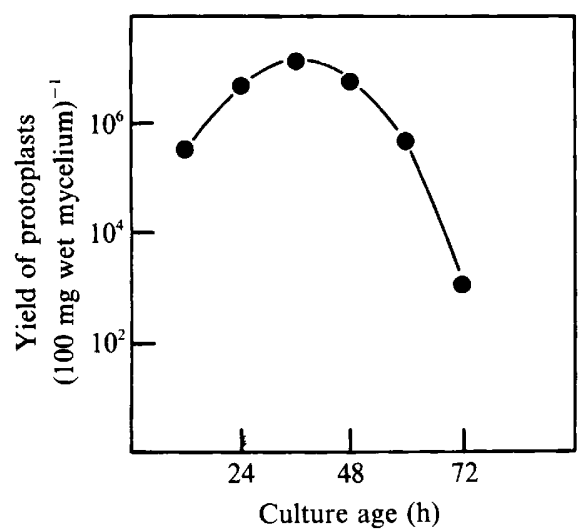

Fig. 1. Influence of culture age on the release of protoplasts. Conditions for the preparation of protoplasts: $100 \mathrm{mg}$ wet mycelium $\mathrm{ml}^{-1}$ and $7 \mathrm{mg}$ Novozym $234 \mathrm{ml}^{-1}$ in $1 \mathrm{mll} 1.1 \mathrm{M}$-sucrose, $\mathrm{pH} \mathrm{5.5}$, were incubated at $37^{\circ} \mathrm{C}$ for $5 \mathrm{~h}$. Values are means of four independent experiments.

$\mathrm{MgSO}_{4}$ in contrast to about $6 \times 10^{5}$ protoplasts with $1 \cdot 1 \mathrm{M}$-sucrose under the same conditions.

Protoplast formation was also affected by the age of the mycelium. Fig. 1 shows that the highest yields were achieved when the mycelium had been grown for $36 \mathrm{~h}$. Stored for several days at $6{ }^{\circ} \mathrm{C}$ the protoplasts were more stable in $1.1 \mathrm{M}$-sucrose or sorbitol, than in $0.6 \mathrm{M}-\mathrm{MgSO}_{4}$. During storage in these three osmotic stabilizers the protoplasts neither increased in volume nor generated a new cell wall.

\section{Regeneration of protoplasts}

The relative density of the protoplasts varied independently of the osmotic stabilizer. In $1 \cdot 1 \mathrm{M}$-sucrose as well as in $0.6 \mathrm{M}-\mathrm{MgSO}_{4}$ two types of protoplasts were observed: dense protoplasts sedimented by gravity and floating protoplasts possessing a large vacuole. Both were capable of generating new walls; $24 \%$ of the floating and $17 \%$ of the sedimenting protoplasts regenerated hyphae when they were cultured on agar. Morphological changes were detected after $12 \mathrm{~h}$ incubation when the smooth surface of the protoplasts became irregularly shaped and germ tubes started to emerge. Extended hyphae appeared after $20 \mathrm{~h}$ and $4 \mathrm{~h}$ later branching was observed.

The regenerated protoplasts were assayed for production of extracellular, water-soluble $1,3-\beta-/ 1,6-\beta$-glucan. No differences in growth and polysaccharide production were found between submerged cultures of regenerated protoplasts and normal mycelium.

Distribution and stability of 1,3- $\beta$-glucan synthase activity in cell-free extracts

Different fractions of cell-free extracts obtained by centrifugation at $34000 \mathrm{~g}$ for $1 \mathrm{~h}$ were assayed for $1,3-\beta$ glucan synthase activity. The highest specific $1,3-\beta-$ glucan synthase activity of 9346 c.p.m. (mg protein) ${ }^{-1}$ $\mathrm{min}^{-1}$ was found in the particulate enzyme fraction from disrupted mycelium (pellet, $34000 \mathrm{~g}, 1 \mathrm{~h}$ ). In the soluble fraction (supernatant $34000 \mathrm{~g}, 1 \mathrm{~h}$ ) only $0.5 \%$ of the specific 1,3- $\beta$-glucan synthase activity of the particulate enzyme preparation from disrupted mycelium was found. The specific 1,3- $\beta$-glucan synthase activity of the membrane fraction from disrupted protoplasts (pellet, $34000 \mathrm{~g}, 1 \mathrm{~h}$ ) was only $42 \%$ of that from disrupted mycelium. Therefore, in all subsequent experiments the membrane fraction from disrupted mycelium was used as enzyme source. Almost no 1,3- $\beta$-glucan synthase activity could be detected in the soluble fraction (supernatant, $34000 \mathrm{~g}, 1 \mathrm{~h}$ ) of cell-free extracts from 


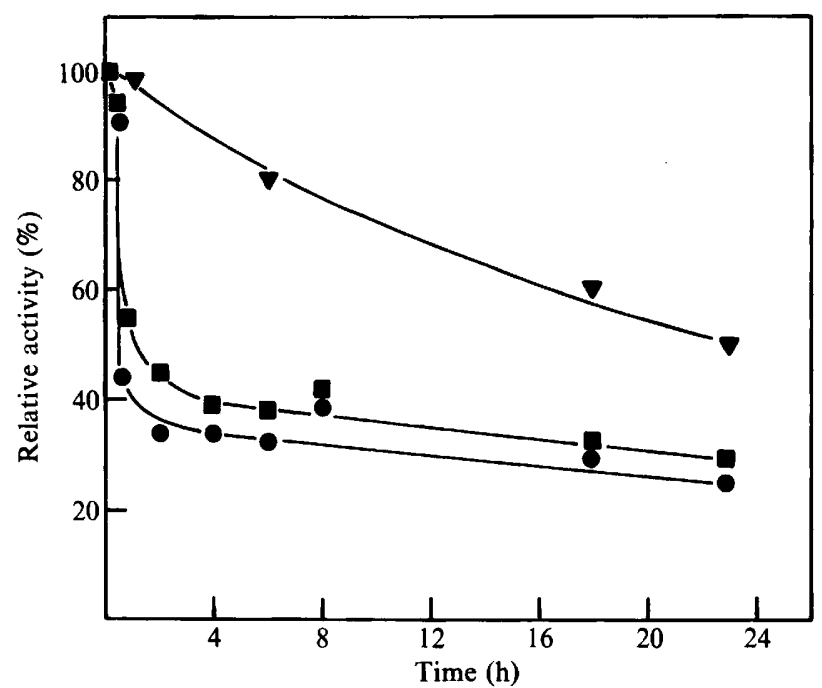

Fig. 2. Stability of 1,3- $\beta$-glucan synthase activity. The particulate enzyme fraction $(34000 \mathrm{~g}, 1 \mathrm{~h})$ was stored in $0.05 \mathrm{M}$-Tris/HCl buffer, $\mathrm{pH} 7.5$, at $-20^{\circ} \mathrm{C}(\nabla)$, at $5^{\circ} \mathrm{C}(\square)$ and at $25^{\circ} \mathrm{C}(\boldsymbol{O})$. Relative activity was expressed as the percentage of $\left[\mathrm{U}^{-14} \mathrm{C}\right]$ glucose incorporated into $1,3-\beta$-glucan under standard assay conditions. Values are means of at least two independent experiments.

disrupted protoplasts. This indicated that the 1,3- $\beta$ glucan synthase was located at the plasma membrane.

The particulate $1,3-\beta$-glucan synthase fraction, stored in $0.05 \mathrm{M}$-Tris/ $\mathrm{HCl}$ buffer, $\mathrm{pH} 7.5$, at $5{ }^{\circ} \mathrm{C}$ and $25^{\circ} \mathrm{C}$ lost $50 \%$ of its activity after 30 and $60 \mathrm{~min}$, respectively. However, when stored at $-20^{\circ} \mathrm{C}$ in $0.05 \mathrm{M}$-Tris/ $\mathrm{HCl}$ buffer, pH 7.5, a half-life of $23 \mathrm{~h}$ was measured (Fig. 2), which could not be enhanced by the addition of $50 \%$ $(w / v)$ glycerol.

\section{$p H$ value, temperature optimum and kinetics of 1,3- $\beta$-glucan synthase activity}

The incorporation of [U- $\left.{ }^{14} \mathrm{C}\right]$ glucose from labelled UDPglucose into $1,3-\beta$-glucan was linear for $20 \mathrm{~min}$. The optimum $\mathrm{pH}$ value and temperature for $1,3-\beta$-glucan synthase activity were 7.5 and $25^{\circ} \mathrm{C}$, respectively. The apparent $K_{\mathrm{m}}$ value for UDP-glucose was $0.54 \mathrm{mM}$.

\section{Activators and inhibitors of 1,3- $\beta$-glucan synthase activity}

ATP and GTP were almost equally effective in activating the 1,3- $\beta$-glucan synthase. At a concentration of $0.2 \mathrm{mM}$ they did not essentially enhance the enzyme activity, whereas at $0.5 \mathrm{~mm}$ it was stimulated by 20 to $25 \%$, and at $1 \mathrm{~mm}$ by $50 \%$ (ATP) and $59 \%$ (GTP). $1,3-\beta$ Glucan synthase activity was not affected by the presence of $1 \mathrm{mM}$-EDTA, but at a concentration of $10 \mathrm{~mm}$ enzyme activity was reduced to $36 \% . \mathrm{Hg}^{2+}(1 \mathrm{mM})$ inhibited $80 \%$ of $1,3-\beta$-glucan synthase activity, while
7 mM-cellobiose stimulated the enzyme activity by about $20 \%$.

\section{Analysis of the 1,3- $\beta$-glucan synthase product}

The product synthesized by the particulate enzyme fraction $(34000 \mathrm{~g}, 1 \mathrm{~h})$ was isolated by precipitation with $70 \%(\mathrm{v} / \mathrm{v})$ ethanol without solubilization. Its solubility after $24 \mathrm{~h}$ shaking at room temperature was determined. Of the reaction product $34 \%$ was soluble in water whereas $63 \%$ could be dissolved in $0.5 \mathrm{M}-\mathrm{NaOH}$ and $87 \%$ in $5 \mathrm{M}-\mathrm{NaOH}$. The 1,3- $\beta$-glucan synthase product was totally soluble in DMSO.

Comparing the ${ }^{13} \mathrm{C}$ NMR spectra of the 1,3- $\beta$-glucan synthase product and the extracellular $1,3-\beta-/ 1,6-\beta-$ glucan (scleroglucan) from Scl. glucanicum in Fig. 3 it is evident that the spectra are almost identical. They differ mainly in the ratio of integral intensity for the signals at 102.9 p.p.m. in the 86 p.p.m. and 60 p.p.m. region. The signal at 102.9 p.p.m. is due to $\mathrm{C}-1$ carbons and the signals in the 86 p.p.m. region can be attributed to C-3 carbons involved in the $1,3-\beta$-glucosidic linkage. The chemical shifts of the free hydroxymethyl C-6 carbons are found in the 60 p.p.m. region (Rinaudo \& Vincendon, 1982). The integral intensity of the signals in the 103 p.p.m. and in the 86 or 60 p.p.m. region gave a ratio of $1: 0.725$ for extracellular $1,3-\beta-/ 1,6-\beta$-glucan and $1: 0.9$ for the 1,3- $\beta$-glucan synthase product (Fig. 3). These ratios could imply that a single glucose group is $1,6-\beta-$ linked to every third monomer of the main $1,3-\beta$-glucan chain in the case of extracellular $1,3-\beta-/ 1,6-\beta$-glucan (Rinaudo \& Vincendon, 1982) and to every ninth monomer in the case of the 1,3- $\beta$-glucan synthase product.

On the other hand, after incubation of the 1,3- $\beta$-glucan synthase product with laminarinase from Penicillium sp., which was found to be an exo-1,3- $\beta$-glucanase, as shown below, the only radioactive product was glucose. Unlabelled gentiobiose was also detected. HPLC analysis revealed that glucose accounted for about $90 \%$ and gentiobiose for about $10 \%$ of the hydrolysis products. The exo-1,3- $\beta$-glucanase character of the laminarinase from Penicillium sp. was demonstrated by its high activity towards laminarin, a smaller one against extracellular $1,3-\beta-/ 1,6-\beta$-glucan $(23 \%$ of the activity towards laminarin) and a very small activity towards pustulan ( $2 \%$ of the activity towards laminarin). No activity was detected against periodate-oxidized laminarin, lichenan, amylose and sodium carboxymethylcellulose. On incubating laminarin and extracellular $1,3-\beta$ $/ 1,6-\beta$-glucan under the same conditions as the $1,3-\beta$ glucan synthase product with laminarinase (exo-1,3- $\beta$ glucanase) from Penicillium sp. only glucose or glucose and gentiobiose, respectively, were detected by TLC as hydrolysis products. 
$(a)$

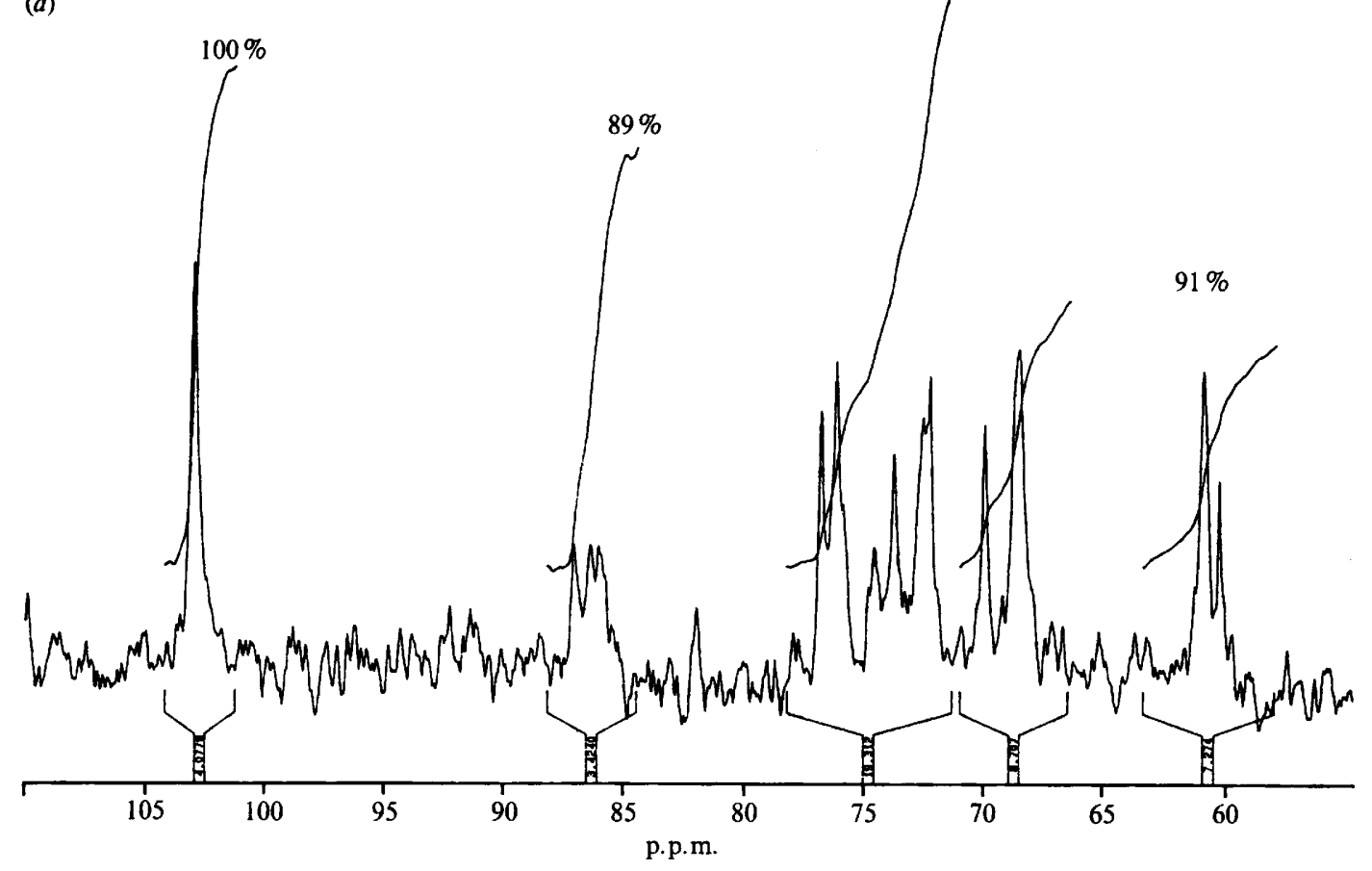

(b)

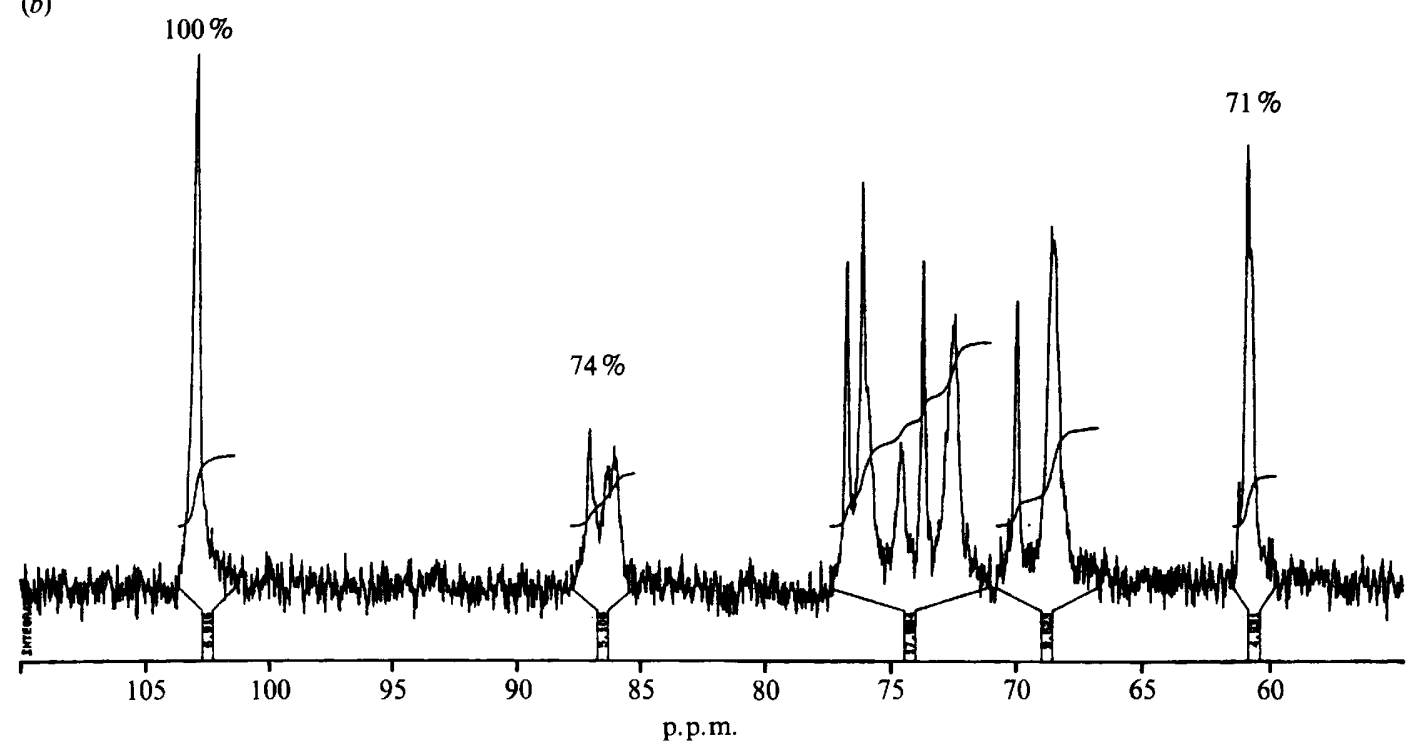

Fig. $3 .{ }^{13} \mathrm{C}$ NMR spectra of the $1,3-\beta$-glucan synthase product $(a)$ and the extracellular, water-soluble $1,3-\beta-/ 1,6-\beta$-glucan $(b)$ in DMSO-d $_{6}$ at $80^{\circ} \mathrm{C}$.

From these results it can be concluded that the product synthesized by the particulate enzyme fraction $(34000 \mathrm{~g}$ $1 \mathrm{~h}$ ) is a linear $1,3-\beta$-glucan. The few $1,6-\beta$-linked glucose groups demonstrated by the ${ }^{13} \mathrm{C}$ NMR spectrum and the appearance of small amounts of unlabelled gentiobiose indicated that the linear $1,3-\beta$-glucan, synthesized in vitro, was associated with some $1,3-\beta / 1,6-\beta$-glucan.

\section{Discussion}

Since the nature of cell wall constituents in Scl. glucanicum is not known, various wall lytic enzyme preparations have been applied for generating protoplasts. Novozym 234 was the most effective, providing a higher number of protoplasts than the mixture of a 
$\beta$-glucuronidase-containing enzyme preparation from $H$. pomatia and a laminarinase preparation from Penicillium sp. Novozym 234 has proved very effective when applied to other fungal species (de Vries \& Wessels, 1972, 1973; Hamlyn et al., 1981; Jacobsen et al., 1985; Deshpande et al., 1987).

Floating protoplasts from Scl. glucanicum reverted to hyphal growth in the same way as those from Sch. commune and Conidiobolus lamprauges by extruding a germ tube from a thick walled spherical structure; however, their reversion frequency of $24 \%$ was remarkably lower than those of 50 and $65 \%$ of the floating protoplasts from Sch. commune and C. lamprauges (de Vries \& Wessels, 1975; Ishikawa \& Oishi, 1985). On the other hand, $17 \%$ of the sedimenting protoplasts from $\mathrm{Scl}$. glucanicum but only $5 \%$ to $10 \%$ of those from $S c h$. commune reverted to hyphal growth (de Vries \& Wessels, 1975).

The almost exclusive presence of 1,3- $\beta$-glucan synthase in the $34000 \mathrm{~g}$ pellet from disrupted protoplasts of $S c l$. glucanicum suggests that it is located at the plasma membrane, as is the case with $1,3-\beta$-glucan synthases from Sac. cerevisiae (Shematek et al., 1980), Candida albicans (Andaluz et al., 1986), Saprolegnia monoica (Girard \& Fèvre, 1984), Entomophaga aulicae and E. muscae (Beauvais \& Latgé, 1989). Like many other 1,3- $\beta$ glucan synthases (San-Blas, 1979; Shematek et al., 1980; Quigley \& Selitrennikoff, 1984; Kang \& Cabib, 1986; Finkelman \& Vardanis, 1987; Kominato et al., 1987; Beauvais \& Latgé, 1989) that from Scl. glucanicum was found to be rather unstable. This was shown by the rather short period $(20 \mathrm{~min})$ during which $\left[\mathrm{U}-{ }^{14} \mathrm{C}\right]$ glucose was incorporated into $1,3-\beta$-glucan and by the enzyme's halflife of 30 and $60 \mathrm{~min}$ at 5 and $25^{\circ} \mathrm{C}$, respectively. The half-life increased to $23 \mathrm{~h}$ when the particulate enzyme preparation was stored at $-20{ }^{\circ} \mathrm{C}$. The $K_{\mathrm{m}}$ value of $0.54 \mathrm{~mm}$ for UDP-glucose of the particulate 1,3- $\beta$-glucan synthase from Scl. glucanicum and the optimum $\mathrm{pH}$ value and temperature of 7.5 and $25^{\circ} \mathrm{C}$ for its activity were within the range of other fungal 1,3- $\beta$-glucan synthases (Lopez-Romero \& Ruiz-Herrera, 1978; San-Blas, 1979; Shematek et al., 1980; Orlean, 1982; Wang \& BartnickiGarcia, 1982; Leal et al., 1984; Quigley \& Selitrennikoff, 1984; Szaniszlo et al., 1985; Finkelman \& Vardanis, 1987; Kominato et al., 1987).

The stimulation of 1,3- $\beta$-glucan synthase from $\mathrm{Scl}$. glucanicum by ATP or GTP was considerably lower than previously reported for some yeasts and other fungi (Shematek \& Cabib, 1980; Orlean, 1982; Szaniszlo et al., 1985; Kominato et al., 1987). Furthermore, different particulate enzyme preparations from $S c l$. glucanicum greatly differed in their response to stimulation by GTP. With 1 mM-GTP two preparations showed a $1 \cdot 6$-fold increase of $1,3-\beta$-glucan synthase activity but one was not stimulated at all (data not shown). This may be an indication of the presence of a labile component in the activating system (Szaniszlo et al., 1985; Kang \& Cabib, 1986).

The polysaccharide formed in the reaction catalysed by the 1,3- $\beta$-glucan synthase from $S c l$. glucanicum was almost totally solubilized by $24 \mathrm{~h}$ shaking in $5.0 \mathrm{M}-\mathrm{NaOH}$ or DMSO at room temperature. Under the same conditions about one-third of it was soluble in water. This pattern is consistent with that observed for a 1,3- $\beta$ glucan predominant at the very tip of the hyphal apex during growth of Sch. commune. This hot-water-soluble $1,3-\beta$-glucan was suggested to be a precursor for the alkali-insoluble chitin- $\beta$-glucan complex in the cell wall (Wessels et al., 1983). ${ }^{13} \mathrm{C}$ NMR spectra of the product synthesized from UDP-[U-14C]glucose by the $1,3-\beta-$ glucan synthase from $S c l$. glucanicum suggested that labelled linear $1,3-\beta$-glucan was associated with some unlabelled $1,3-\beta-/ 1,6-\beta$-glucan. This suggestion was supported by the finding that hydrolysis of the reaction product by an exo-1,3- $\beta$-glucanase (laminarinase) from Penicillium sp. resulted in glucose as the only radioactive product and very small amounts of unlabelled gentiobiose. Since the exo-1,3- $\beta$-glucanase exhibited a very low activity towards pustulan its ability to cleave the $1,6-\beta$ linkages of the $1,3-\beta-/ 1,6-\beta$-glucan was studied: the only hydrolysis products were glucose and gentiobiose. All these results indicate that the reaction product of the 1,3$\beta$-glucan synthase from $S c l$. glucanicum was a linear polysaccharide consisting of $1,3-\beta$-linked glucose residues.

This work was supported by a grant (03-8807) from the Bundesminister für Forschung und Technologie, FRG.

We thank Dr V. Wray of the Gesellschaft für Biotechnologische Forschung mbH, D-3300 Braunschweig, for recording the NMR spectra.

\section{References}

Andaluz, E., Guillén, A. \& Larriba, G. (1986). Preliminary evidence for a glucan acceptor in the yeast Candida albicans. Biochemical Journal 240, 495-502.

Beauvais, A. \& Latgé, J.-P. (1989). Chitin and $\beta$ (1-3)glucan synthase in the protoplastic entomophthorales. Archives of Microbiology 152, 229-236.

CAtley, B, J. (1983). Regulation of yeast and fungal polysaccharides excluding chitin and cellulose. Progress in Industrial Microbiology 18, 129-200.

CERENIUS, L. \& SöDERHÄLL, K. (1984). Isolation and properties of $\beta$ glucan synthetase from the aquatic fungus Aphanomyces astaci. Physiologia Plantarum 60, 247-252.

DeshPande, M. V., Balkrishnan, H., RanjekaR, P. K. \& ShankaR, V. (1987). Isolation and immobilization of Sclerotium rolfsii protoplasts. Biotechnology Letters 9, 49-52.

Finkelman, M. A. J. \& VARDaNIS, A. (1987). Synthesis of $\beta$-glucan by cell-free extracts of Aureobasidium pullulans. Canadian Journal of Microbiology 33, 123-127. 
GIRARD, V. \& FÈVRE, M. (1984). Distribution of (1-3)- $\beta$ - and (1-4)- $\beta$ glucan synthases along the hyphae of Saprolegnia monoica. Journal of General Microbiology 130, 1557-1562.

Goldstein, I. J., Hay, G. W., Lewis, B. A. \& SMith, F. (1965). Controlled degradation of polysaccharides by periodate oxidation, reduction and hydrolysis. Methods in Carbohydrate Chemistry 5, 361369.

Gooday, G. W. \& Trinci, A. J. P. (1980). Wall structure and biosynthesis in fungi. Symposia of the Society for General Microbiology 30, 207-251.

Halleck, F. E. (1967). Polysaccharides and methods for the production thereof. US Patent No. 3301848.

Hamlyn, P. F., Bradshaw, R. E., Melion, F. M., Santiago, C. M., WILSON, J. M. \& PEBERDY, J. F. (1981). Efficient protoplast isolation from fungi using commercial enzymes. Enzyme and Microbial Technology 3, 321-325.

IsHIKAWA, F. \& OISHI, K. (1985). Formation and regeneration of protoplasts from Conidiobolus lamprauges. Journal of General Microbiology 131, 3311-3316.

Jacobsen, T., Jensen, B., Olsen, J. \& Allermann, K. (1985). Preparation of protoplasts from mycelium and arthroconidia of Geotrichum candidum. Canadian Journal of Microbiology 31, 93-96.

Johnson, J. JR, KIRKwood, S., Misaki, A., Nelson, T. E., Scaletti, J. V. \& SMITH, F. (1963). Structure of a new glucan. Chemistry and Industry, 820-822.

KANG, M. S. \& CABIB, E. (1986). Regulation of fungal cell wall growth: A guanine nucleotide-binding, proteinaceous component required for activity of (1-3)- $\beta$-D-glucan synthase. Proceedings of the National Academy of Sciences of the United States of America 83, 5808-5812.

Kominato, M., KamimiYa, S. \& Tanaka, H. (1987). Preparation and properties of $\beta$-glucan synthase of Pyricularia oryzae $\mathrm{P}_{2}$. Agricultural and Biological Chemistry 51, 755-761.

KREBS, K. G., HEUSSER, D. \& WimMER, H. (1967). Sprühreagentien. In Dünnschichtchromatographie, pp. 813-859. Edited by E. Stahl. Berlin: Springer Verlag.

Leal, F., Ruiz-HerRera, J., Villanueva, J. R. \& LarRiBa, G. (1984). An examination of factors affecting the instability of Saccharomyces cerevisiae glucan synthetase in cell free extracts. Archives of Microbiology 137, 209-214.

Lopez-Romero, E. \& Ruiz-Herrera, J. (1978). Properties of $\beta$-glucan synthetase from Saccharomyces cerevisiae. Antonie van Leeuwenhoek 44, 329-339.

ORLEAN, P. A. B. (1982). 1,3- $\beta$-D-Glucan synthase from budding and filamentous cultures of the dimorphic fungus Candida albicans. European Journal of Biochemistry 127, 397-403.
Quigley, D. R. \& SelitrenNikofF, C. P. (1984). $\beta(1-3)$ Glucan synthase activity of Neurospora crassa: stabilization and partial characterization. Experimental Mycology 8, 202-214.

RAPP, P. (1989). 1,3- $\beta$-Glucanase, 1,6- $\beta$-glucanase and $\beta$-glucosidase activities of Sclerotium glucanicum: synthesis and properties. Journal of General Microbiology 135, 2847-2858.

RAPP, P., BeCK, C. H. \& WAGNER, F. (1979). Formation of expolysaccharides by Rhodococcus erythropolis and partial characterization of a heteropolysaccharide of high molecular weight. European Journal of Applied Microbiology and Biotechnology 7, 67-78.

RINAUDO, M. \& VINCENDON, M. (1982). ${ }^{13} \mathrm{C}$ NMR structural investigation of scleroglucan. Carbohydrate Polymers 2, 135-144.

RoDGers, N. E. (1973). Scleroglucan. In Industrial Gums, pp. 499-511. Edited by R. L. Whistler \& J. N. Bemiller. London: Academic Press.

SAN-BLAS, G. (1979). Biosynthesis of glucans by subcellular fractions of Paracoccidioides brasiliensis. Experimental Mycology 3, 249-258.

SHEMATEK, E. M. \& CABIB, E. (1980). Biosynthesis of the yeast cell wall. II. Regulation of $\beta$-(1-3)glucan synthetase by ATP and GTP. Journal of Biological Chemistry 255, 895-902.

ShEMATEK, E. M., BRAaTZ, J. A. \& CABIB, E. (1980). Biosynthesis of the yeast cell wall. I. Preparation and properties of $\beta-(1-3)$ glucan synthetase. Journal of Biological Chemistry 255, 888-894.

SOMOGYI, M. (1952). Notes on sugar determination. Journal of Biological Chemistry 195, 19-28.

Szaniszlo, P. J., Kang, M. S. \& Cabib, E. (1985). Stimulation of $\beta(1-3)$ glucan synthetase of various fungi by nucleoside triphosphates: generalized regulatory mechanism for cell wall biosynthesis. Journal of Bacteriology 161, 1188-1194.

DE VRIES, O. M. H. \& WeSSELS, J. G. H. (1972). Release of protoplasts from Schizophyllum commune by a lytic enzyme preparation from Trichoderma viride. Journal of General Microbiology 73, 13-22.

DE VRIES, O. M. H. \& WesseLs, J. G. H. (1973). Release of protoplasts from Schizophyllum commune by combined action of purified $\alpha-1,3-$ glucanase and chitinase derived from Trichoderma viride. Journal of General Microbiology 76, 319-330.

DE VRIES, O. M. H. \& Wessels, J. G. H. (1975). Chemical analysis of cell wall regeneration and reversion of protoplasts from Schizophyllum commune. Archives of Microbiology 102, 209-218.

WANG, M. C. \& BARTNICKI-GarCIA, S. (1982). Synthesis of noncellulosic cell-wall $\beta$-glucan by cell-free extracts from zoospores and cysts of Phytophthora palmivora. Experimental Mycology 6, 125-135.

Wessels, J. G. H., Sietsma, J. H. \& SonNenberG, A. S. M. (1983). Wall synthesis and assembly during hyphal morphogenesis in Schizophyllum commune. Journal of General Microbiology 129, 1607-1616. 